\title{
Bone Cancer cM0 TNM Finding v8
}

National Cancer Institute

\section{Source}

National Cancer Institute. Bone Cancer cMO TNM Finding v8. NCI Thesaurus. Code

C136564.

Bone cancer without distant metastasis. (from AJCC 8th Ed.) 